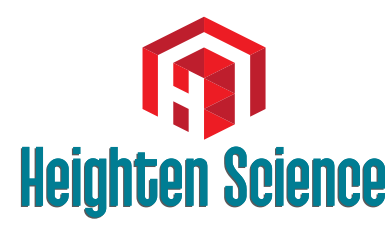

P U B L I C A T I O N S Corporation

Review Article

\title{
Host biomarkers for early diagnosis of infectious diseases: A comprehensive review
}

\author{
Arindam Chakraborty ${ }^{1 *}$ and Singh Monica ${ }^{2}$ \\ ${ }^{1}$ Associate Professor, Department of Microbiology, Motilal Nehru Medical College, Allahabad, \\ Uttar Pradesh, India \\ ${ }^{2}$ Assistant Professor, Department of Microbiology, Motilal Nehru Medical College, Allahabad, \\ Uttar Pradesh, India
}

*Address for Correspondence: Dr. Arindam Chakraborty, Associate Professor, Department of Microbiology, Motilal Nehru Medical College, Allahabad, Uttar Pradesh, 211002, India, Tel: +917408881369.

Email: arindamchakraborty@hotmail.com

Submitted: 15 May 2019

Approved: 04 June 2019

Published: 05 June 2019

Copyright: @ 2019 Chakraborty A, et al. This is an open access article distributed under the Creative Commons Attribution License, which permits unrestricted use, distribution, and reproduction in any medium, provided the original work is properly cited

Check for updates

\section{Abstract}

Biomarkers have been used in the diagnosis of disease and other conditions for many decades. There are diverse ranges of analytical targets, including metabolites, nucleic acids and proteins were used as a biomarker. Clinical diagnoses already rely heavily on these for patient disease classification, management, and informing treatment and care pathways. For that there is always a need of rapid and point of care test. However, until fairly recently, studies of biomarker efficacy in a clinical setting were mainly limited to single or dual use, and the landscape was complex, confused, and often inconsistent. Few candidates emerged from this somewhat clouded picture: C-reactive protein, procalcitonin (PCT) for sepsis, ADA for mycobacterium tuberculosis and a Circulating miRNAs serve as molecular markers for diverse physiological and pathological conditions.

\section{Introduction}

Effective biomarker are utmost important for the early diagnosis of various diseases. Biomarkers have been used in the diagnosis of diseases and other conditions for many decades and include a diverse range of analytical targets. All over the world acute febrile illness is a common presentation in any primary care settings [1,2]. Although there are infective and non-infective causes for febrile illness, the most common causes of AFI in India are dengue and malaria. Other than AFI the diagnosis of tuberculosis (TB) continues to be a challenge in clinical practices [3]. Routine diagnostic methods are very useful but do not provide enough sensitivity and specificity. For many decades diverse range of analytical targets such as metabolites, nucleic acids, proteins were used as biomarkers [4]. Out of many tested biomarker CRP, procalcitonin and adenosine deaminase were emerged a potential biomarker for point of care platforms. Clinical diagnoses already rely heavily on these for patient disease classification, management and informing treatment and care pathways [1].

In recent year there are different new biomarker known as miRNA and IP-10 which are widely studied to know the potential of disease diagnosis. The primary objective of this comprehensive review was to summarize the role of host biomarkers in diagnosis of infectious diseases.

\section{Methods}

\section{Literature survey}

A literature search of Medline, PubMed, and Google Scholar was done using the term 
"biomarker, detection of biomarker, role of biomarker in diseases diagnosis, miRNA. On the basis of title and displayed abstract, articles were chosen for the selected topics. Among the non-English articles, only those with abstract in English were reviewed and included. Of the published articles, 38 original articles and 12 reviewed were excluded in which studies were mainly focused on role of biomarker in infectious diseases diagnosis.

\section{C-reactive protein}

CRP, named for its capacity to precipitate the somatic C-polysaccharide of Streptococcus pneumoniae, was the first acute-phase protein to be described and is an intricately sensitive systemic marker of inflammation and tissue damage [5].CRP is synthesized primarily in liver hepatocytes but also by smooth muscle cells, macrophages, endothelial cells, lymphocytes, and adipocytes. C-reactive protein exhibits elevated expression during inflammatory conditions such as rheumatoid arthritis, some cardiovascular diseases, and infection [6]. In healthy young adult volunteer blood donors, the median concentration of CRP is $0.8 \mathrm{mg} / \mathrm{l}$, the $90^{\text {th }}$ centile is $3.0 \mathrm{mg} / \mathrm{l}$, and the 99th centile is $10 \mathrm{mg} / \mathrm{l}$, but, following an acute-phase stimulus, values may increase from less than $50 \mathrm{mg} / \mathrm{l}$ to more than $500 \mathrm{mg} / \mathrm{l}$, that is, 10,000-fold [7]. CRP was the most frequently studied host biomarker in this review and the majority of these studies $(33 / 36$; 92\%) reported statistically significant differences in CRP levels measured in patients with bacterial and those with non-bacterial infections. Half of the studies $(18 / 36 ; 47 \%)$ reported sensitivity and specificity at ranges of $61.2 \%-100 \%$ and $26 \%$ $100 \%$ respectively to identify bacterial infections [3,8-10]. All studies comparing CRP levels in blood specimen of patients with meningitis $(5 / 5)$ reported statistically significant differences in CRP levels between the bacterial and viral group, with higher levels seen in bacterial infections [11-13]. yet an another study investigators examined CRP in bacterial and fungal sepsis within a neonatal intensive care population in Turkey and found that CRP levels were lower in bacterial sepsis patients (mean $11.4 \mathrm{mg} / \mathrm{l}$ ) than in fungal sepsis patients (mean $28.0 \mathrm{mg} / \mathrm{l}, \mathrm{p}=0.026$ ) [14]. However, they did not report diagnostic performance characteristics. A study in Malawian children found significantly higher CRP levels in bacterial infections compared to patients with viral causes (median 185.4 vs. $18.3 \mathrm{mg} / \mathrm{l}, \mathrm{p}<0.001$ ) [10]. However, in children with malaria, CRP levels were not significantly higher during bacterial than viral pneumonia (median 217.4 vs. $96.8 \mathrm{mg} / \mathrm{l}, \mathrm{p}=0.052$ ), indicating that CRP might be valuable as a diagnostic only after malaria has been ruled out [3].

\section{Procalcitonin}

Procalcitonin (PCT) is used as a biomarker for the diagnosis of bacterial infection such as sepsis and septic shock [15]. PCT is produced ubiquitously in response to endotoxin or mediators released in response to bacterial infection (IL-1 $\beta$, TNF and IL-6) and strongly correlates with extent and severity of bacterial infections, it also helpful to distinguish bacterial infections from viral illnesses [16,17]. For the diseases diagnosis and prognosis PCT shows a favorable kinetic profile for use as a clinical marker: it promptly increase within 6 to 12 hours upon stimulation and circulating PCT levels halve daily when the infection is controlled by the host immune system or antibiotic therapy [18]. PCT correlates with bacterial load and severity of infection $[19,20]$.

At present there are no gold standard exist for the detection of blood stream infection as the chances of contamination is very high with coagulase negative staphylococci while collecting the blood sample. At this point PCT demonstrated a batter role for the diagnosis of sepsis in compare to WBC and CRP. In a study researcher had observed that a cut off of $0.1 \mathrm{ug} / \mathrm{L}$, PCT had a very high sensitivity to exclude true infection $[19,21]$. Yet in another study by Muller et al., observed that PCT cut off of $0.25 \mathrm{ug} / \mathrm{l}$ was most helpful to exclude bacteremia [22]. 
For upper and lower respiratory tract infection in ICU patients with sepsis and post-operative infections, many studies have shown the effectiveness of using PCT algorithms to guide antibiotic choices [23,24]. So, PCT levels should be always evaluated in the context of a careful clinical and microbiological assessment. As the kinetics of PCT are of particular diagnostic and prognostic interest, repeated measurements should be performed if possible, especially in seriously ill patients if antibiotics are withheld. The limitations of every PCT measurement include false-positive and false-negative results [25]. Unspecific elevations of PCT levels in the absence of a bacterial infection can usually be seen in situations of massive cell death, for example after severe trauma or surgery $[17,26,27]$. In these situations, PCT values are usually only moderately elevated and show a rapid decline in follow-up measurements. On the other hand, falsely low PCT levels typically seen during the early course or localized state of an infection, often show an increase in the follow-up measurements. Thus, highly sensitive PCT assays are required, as subtle changes of PCT at very low concentrations can be monitored, increasing the sensitivity of the test and thus the safety of patients.

\section{Adenosine deaminase (ADA)}

$\mathrm{ADA}$ is an enzyme catalyzing the deamination reaction from adenosine to inosine. It is also an essential enzyme of the purine catabolic pathway [28]. ADA acts in proliferation and differentiation of lymphocyte, especially $\mathrm{T}$ lymphocyte. It also acts in maturation of monocytes transforming them to macrophage. ADA is a significant indicator of active cellular immunity. It increases in biological fluids in the course of infectious disease characterized by micro-organisms infecting the macrophages [29]. ADA has been proposed to be a useful surrogate marker for TB because it can be detected in body fluids such as pleural, pericardial and peritoneal fluid. The levels of ADA increase in TB because of the stimulation of T cells by mycobacterial antigens [30].

Adenosine deaminase (ADA) has been developed and widely used for the diagnosis of TB due to its simplicity, low cost, and quickly available results. Many studies have confirmed the high sensitivity and specificity of ADA (sensitivity $92 \%$ and specificity 89\%) for early diagnosis of EPTB, such as tuberculous pleuritis, pericarditis, ascites and meningitis [32,33].

The main reason for the increased ADA levels in pleural effusion is the movement of T lymphocytes toward this area. When TB infection is controlled, growth-markers of lymphocytes decrease; leucocytes will decrease in serum ADA levels concurrent with the decrease in lymphocytes. Because of this, serum ADA level could be utilized as a treatment response index $[29,30]$.

ADA assays can be performed in many health care centers with limited diagnostic facilities other than mycobacterial culture, PCR etc. In addition, it is cheap and it has good sensitivity. ADA may be used for early diagnosis of TB, especially in case of negative AFB smear from the body specimens. However, culture is still the gold standard and mandatory for the confirmatory diagnosis [33]. Many studies had reported about the correlation of $\mathrm{ADA}$ value in pulmonary $\mathrm{TB}$ with the healthy population, where the found significant positive correlation in ADA value in pulmonary TB patient $[34,35]$. In another study by Gupta et al., 's find sensitivity, specificity, positive predictive value, and negative predictive value were $92.8 \%, 90 \%, 92.8 \%$, and $90 \%$, respectively, for diagnosis of TB in pleural effusion with an ADA level of more than 40 [36].

However elevated level of ADA have been reported in peritoneal, meningeal, pleural pericardial effusions in several nn-non-tubercuer diseases like hepatic cirrhosis, thyphoid fever, infectious mononucleosis, brucellosis and bronchogenic carcinoma involving simulation of cell mediated immunity. So it's the job of health care worker to clinically correlate and corroborate the result with the other diagnostic finding. 
miRNA

miRNAs are small non coding RNAs molecules regulating multiple biological processes by interfering with mRNA translation" [37]. miRNAs are the largest gene defined as single-stranded RNAs $\sim 22 \mathrm{nt}$ in length (ranging 19-25 nt) generated from endogenous transcripts that can form local hairpin structures in silico. Discovery of miRNA resulted into several theories related to the process involved in its regulation and expression. $\mathrm{O}^{\prime}$ Connell et al., describe three stages regaled to the function of miRNAs namely "(i) transcription, (ii) processing and (iii) subcellular localisation" [38]. Currently there are approximately 1,000 human miRNAs sequences were found in mammals and it targets about $60 \%$ of all genes. It plays a pivotal role in various biological processes including cell proliferation, cell cycle, cell growth, tissue organization, apoptosis and different metabolisms. In infectious diseases biology miRNAs play an extensive role in the maintenance of the regulatory signaling at the cellular level, which either provides protection from the disease or favors its persistency by inducing protected or unprotected signaling pathways, respectively [39]. In diseases condition miRNAs are found in serum, which were derived from the infected epithelial cells and other types of immune cells. The changes of several miRNA levels in plasma, serum, urine and saliva have been associated with various diseases [40]. Circulating miRNAs are stable which are protected from endogenous RNAse activity. Several recent studies have established a significant correlation between the miRNA and the cause of diseases [41], therefore, today several miRNAs are being consider as molecular biomarkers for the diagnosis of human infectious diseases such as in tuberculosis, HIV/AIDS, Hepatitis, H.pylori infection [42].

Till date, several miRNAs have been reported as a molecular biomarker in infectious diseases, such as miRNA-150 and miRNA-146b-5p in human immunodeficiency virus (HIV); miRNA-122, miRNA-21, and miRNA-34a in hepatitis; miRNA-361-5p and miRNA-29c in tuberculosis; miRNA-16 and miRNA-451 in malaria and miRNA-181 in Helicobacter pylori infection $[43,44]$.

\section{CXCL10/IP-10}

C-X-C motif chemokine 10 (CXCL10) also known as interferon $\gamma$-induced protein $10 \mathrm{kDa}$ (IP-10) or small-inducible cytokine B10 is a cytokine belonging to the CXC chemokine family. CXCL10 binds CXCR3 receptor to induce chemotaxis, apoptosis, cell growth and angiostasis. Modifications in CXCL10 expression levels have been associated with inflammatory diseases including infectious diseases, immune dysfunction and tumor development. CXCL10 is also recognized as a biomarker that predicts severity of various diseases. However, the mechanism of CXCL10 in the pathogenesis of infectious disease remains unclear.

CXCL10 have been shown to play a role in Helicobacter pylori and Mycoplasma $[45,46]$. Elevation of CXCL10 levels appears to be an early host response to scrub typhus infection [47] and is associated with severity of Legionnaire's disease and tuberculosis (TB) [48]. Antimicrobial treatment significant decreased the level of CXCL10 in a murine model of Mycoplasma pneumonia [46]. Fewer studies on role of CXCL10 in fungal infections have been reported. Fungal infections abrogate CXCL10 expression in human cells. Impaired CXCL10 production contributes to the pathogenesis of cutaneous candidiasis caused by Candida albicans [49]. CXCL10 has been shown to be a novel biomarker for severity of Human African trypanosomiasis (HAT) caused by infection with sub-species of Trypanosoma brucei, Plasmodium falciparum and Plasmodium vivax malaria, Toxoplasma gondii and Leishmania major [50].

\section{Conclusion}

In spite of the emergence of novel biomarkers, biomarker combinations and biomarker detection strategies of critical diseases such as sepsis, meningitis, 
tuberculosis has been difficult and almost nonexistent. There is continued to be many knowledge gaps. Most of the novel biomarkers with strong performance values identified in this review were only evaluated in a small number of patients, indicating that there is a need for standardizing biomarker study methods and reporting performance results. The study gaps need to be delineated for the betterment of the test by collaboratively, by industry, academia, international health organizations and other institutions with the aligned goal of 1.) identifying promising host biomarkers that can distinguish latent tuberculosis and active tuberculosis and also should be able to differentiate between viral, fungal, bacterial \& parasitic infection. 2) Developing these promising biomarkers into affordable rapid POC tests with practical implementation and utility in limited setting.

\section{References}

1. Kapasi AJ, Dittrich S, González IJ, Rodwell TC. Host Biomarkers for Distinguishing Bacterial from Non-Bacterial Causes of Acute Febrile Illness: A Comprehensive Review. PLoS ONE. 2016; 11: e0160278. Ref.: http://bit.ly/2MtsKCM

2. Farrar JHP, Junghanss T, Kang G, Lalloo D, White NJ. Manson's Tropical Diseases. 22nd Edition ed. London, UK: Saunders; 2009. Ref.: http://bit.ly/2ZcWrt9

3. Zhang X, Guo J, Fan S, Li Y, Wei L, et al. Screening and Identification of Six Serum microRNAs as Novel Potential Combination Biomarkers for Pulmonary Tuberculosis Diagnosis. PLoS ONE. 2013; 8: e81076. Ref.: http://bit.ly/2WjBpY6

4. Kempsell KE, Ball G, Szakmany T. Issues in biomarker identification, validation and development for disease diagnostics in Public Health, Expert Review of Molecular Diagnostics. 2016; 16: 4: 383-386. Ref.: http://bit.ly/2WNPOLC

5. Pepys MB, Baltz ML. Acute phase proteins with special reference to C-reactive protein and related proteins (pentaxins) and serum amyloid A protein. Adv Immunol. 1983; 34:141-212. Ref.: http://bit.ly/2XsecnW

6. Du Clos TW, Mold C. C-reactive protein: an activator of innate immunity and a modulator of adaptive immunity. Immunol Res. 2004; 30: 261-277. Ref.: http://bit.ly/2Wj7dfR

7. Shine B, de Beer FC, Pepys MB. Solid phase radioimmunoassays for C-reactive protein. Clin Chim Acta. 1981; 117: 13-23. Ref.: http://bit.ly/2QY5Z8R

8. Elsing C, Ernst S, Kayali N, Stremmel W, Harenberg S. Lipopolysaccharide binding protein, interleukin6 and C-reactive protein in acute gastrointestinal infections: value as biomarkers to reduce unnecessary antibiotic therapy. Infection. 2011; 39: 327-331. Ref.: http://bit.ly/2lzBNx1

9. Weh J, Antoni C, Weiss C, Findeisen P, Ebert M, et al. Discriminatory potential of C-reactive protein cytokines, and fecal markers in infectious gastroenteritis in adults. Diagn Microbiol Infect Dis. 2013; 77: 79-84. Ref.: http://bit.ly/2K49vOa

10. Diez-Padrisa N, Bassat Q, Machevo S, Quinto L, Morais L, et al. Procalcitonin and Creactive protein for invasive bacterial pneumonia diagnosis among children in Mozambique, a malariaendemic area. PLoS One. 2010; 5: e13226. Ref.: http://bit.ly/2Wio2Hw

11. Tamune H, Takeya H, Suzuki W, Tagashira Y, Kuki T, et al. Cerebrospinal fluid/blood glucose ratio as an indicator for bacterial meningitis. The American journal of emergency medicine. 2014; 32: 263-266. Ref.: http://bit.ly/2HWKa6o

12. Viallon A, Desseigne N, Marjollet O, Birynczyk A, Belin M, et al. Meningitis in adult patients with a negative direct cerebrospinal fluid examination: value of cytochemical markers for differential diagnosis. Critical care. 2011; 15: R136. Ref.: http://bit.ly/31g4EPt

13. Ibrahim KA, Abdel-Wahab AA, Ibrahim AS. Diagnostic value of serum procalcitonin levels in children with meningitis: a comparison with blood leukocyte count and C-reactive protein. J Pak Med Assoc. 2011; 61: 346-351. Ref.: http://bit.ly/2lkH2Af

14. Pfister R, Kochanek M, Leygeber T, Brun-Buisson C, Cuquemelle E, et al. Procalcitonin for diagnosis of bacterial pneumonia in critically ill patients during 2009 H1N1 influenza pandemic: a prospective cohort study, systematic review and individual patient data meta-analysis. Critical care. 2014; 18: R44. Ref.: http://bit.ly/2wBF2OG

15. Meisner M. Update on procalcitonin measurement. Ann Lab Med. 2014; 34: 263-273. Ref.: http://bit.ly/2lgiKr2

16. Gogos CA, Drosou E, Bassaris HP, Skoutelis A. Pro- versus anti-inflammatory cytokine profile in 
patients with severe sepsis: a marker for prognosis and future therapeutic options. $J$ Infect Dis. 2000; 181: 176-180. Ref.: http://bit.ly/2WrXqsO

17. Schuetz $P$, Albrich W, Mueller B. Procalcitonin for diagnosis of infection and guide to antibiotic decisions: past, present and future. BMC Med. 2011; 9: 107. Ref.: http://bit.ly/2MuS37y

18. Becker KL, Nylén ES, White JC, Müller B, Snider RH Jr. Procalcitonin and the Calcitonin Gene Family of Peptides in Inflammation, Infection, and Sepsis: A Journey from Calcitonin Back to Its Precursors. J Clin Endocrinol Metab. 2004; 89: 1512-1525. Ref.: http://bit.ly/2KvybhU

19. van Nieuwkoop C, Bonten TN, van't Wout JW, Kuijper EJ, Groeneveld GH, et al. Procalcitonin reflects bacteremia and bacterial load in urosepsis syndrome: a prospective observational study. Crit Care. 2010; 14: R206. Ref.: http://bit.ly/2K06RZA

20. Christ-Crain M, Stolz D, Bingisser R, Muller C, Miedinger D, et al. Procalcitonin guidance of antibiotic therapy in community-acquired pneumonia: a randomized trial. Am J Respir Crit Care Med. 2006; 174: 84-93. Ref.: http://bit.ly/2WepEIT

21. Schuetz P, Mueller B, Trampuz A. Serum procalcitonin for discrimination of blood contamination from bloodstream infection due to coagulase negative staphylococci. Infection. 2007; 35: 352-355. Ref.: http://bit.ly/31bqm6S

22. Muller $F$, Christ-Crain $M$, Bregenzer $T$, Krause $M$, Zimmerli $W$, et al. Procalcitonin levels predict bacteremia in patients with community-acquired pneumonia: a prospective cohort trial. Chest. 2010; 138: 121-129. Ref.: http://bit.ly/2XsLCTy

23. Hochreiter M, Köhler T, Schweiger A, Keck F, Bein B, et al. Procalcitonin to guide duration of antibiotic therapy in intensive care patients: a randomized prospective controlled trial. Crit Care. 2009; 13: R83. Ref.: http://bit.ly/2Zawv1y

24. Nobre V, Harbarth S, Graf JD, Rohner P, Pugin J. Use of procalcitonin to shorten antibiotic treatment duration in septic patients: a randomized trial. Am J Respir Crit Care Med. 2008; 177: 498-505. Ref.: http://bit.ly/2WgZQFF

25. Christ-Crain M, Muller B. Procalcitonin in bacterial infections-hype, hope, more or less? Swiss Med Wkly. 2005; 135: 451-460. Ref.: http://bit.ly/2WkYmKI

26. Uzzan B, Cohen R, Nicolas P, Cucherat M, Perret GY. Procalcitonin as a diagnostic test for sepsis in critically ill adults and after surgery or trauma: a systematic review and meta-analysis. Crit Care Med. 2006; 34: 1996-2003. Ref.: http://bit.ly/2HWKNNi

27. Hunziker S, Hugle T, Schuchardt K, Groeschl I, Schuetz P, et al. The value of serum procalcitonin level for differentiation of infectious from noninfectious causes of fever after orthopaedic surgery. J Bone Joint Surg Am. 92: 138-148. Ref.: http://bit.ly/2ETedtK

28. Kaya S, Cetin ES, Aridogan BC, Arikan S, Demirci M. Adenosine deaminase activity in serum of patients with hepatitis - a useful tool in monitoring clinical status. J Microbiol Immunol Infect. 2007; 40: 288-292. Ref.: http://bit.ly/31e5z2A

29. Cimen F, Ciftci TU, Berktas BM. The relationship between serum adenosine deaminase levels in lung tuberculosis along with drug resistance and the category of tuberculosis. Turkish Respir J. 2008; 9: 20-23.

30. Gakis $C$. Adenosine deaminase (ADA) isoenzymes ADA1 and ADA2: diagnostic and biological role. Eur Respir J. 1996; 9: 632-633. Ref.: http://bit.ly/317ujcZ

31. Greco S, Girardi E, Masciangelo R, Capoccetta GB, Saltini C. Adenosine Deaminase and interferon gamma measurements for the diagnosis of tuberculous pleurisy: a metaanalysis. Int $\mathrm{J}$ Tuberc Lung Dis. 2003; 7: 777-786. Ref.: http://bit.ly/2QOTEDL

32. Saleh MA, Hammad E, Ramadan MM, Abd El-Rahman A, Enein AF. Use of adenosine deaminase measurements and QuantiFERON in the rapid diagnosis of tuberculous peritonitis. $\mathrm{J}$ Med Microbiol. 2012; 61: 514-519. Ref.: http://bit.ly/2WrZy3w

33. Barua R, Hossain M. Adenosine deaminase in diagnosis of tuberculosis: a review. Anwer Khan Mod Med Coll J. 2014; 5: 43-48. Ref.: http://bit.ly/2QPyOnR

34. Jhamaria JP, Jenaw RK, Luh SK, Mathur DK, Parihar HL, et al. Serum adenosine deaminase (ADA) in differential diagnosis of pulmonary tuberculosis and common non tubercular respiratory diseases. Ind J Tub. 1988; 35: 25-27. Ref.: http://bit.ly/2WrDhTv

35. Agarwal MKN, Mukerji PK, Srivastava VML. A study of serum adenosine deaminase activity in sputum negative patients of pulmonary tuberculosis. Ind L Tub. 1991; 38: 139. Ref.: http://bit.ly/2MvQ1UQ 
36. Gupta BK, Bharat V, Bandyopadhyay D. Sensitivity, specificity, negative and positive predictive values of adenosine deaminase in patients of tubercular and non-tubercular serosal effusion in India. $\mathrm{J}$ Clin Med Res. 2010; 2: 121-126. Ref.: http://bit.ly/2linyfK

37. Hammond SM. MicroRNAs as oncogenes. Curr Opin Genet Dev. 2006; 16: 4-9. Ref.: http://bit.ly/2K0Q2y0

38. O'Connell RM, Rao DS, Chaudhuri AA, Baltimore D. Physiological and pathological roles for microRNAs in the immune system. Nat Rev Immunol. 2010; 10: 111-122. Ref.: http://bit.ly/2Z6ZVxq

39. Wang T, Qian X, Wang Z, Wang L, Yu L, Ding Y, et al. Detection of cell free BIRC5 mRNA in effusions and its potential diagnostic value for differentiating malignant and benign effusions. Int $\mathrm{J}$ Cancer. 2009; 125: 1921-1925. Ref.: http://bit.ly/2WiqWvU

40. Faruq O, Vecchione A. microRNA: Diagnostic perspective. Front Med Lausanne. 2015; 2: 51. Ref.: http://bit.ly/2QMKcRl

41. Pandey RK, Sundar S, Prajapati VK. Differential Expression of miRNA Regulates Tcell differentiation and plasticity during visceral leishmaniasis infection. Front. Microbiol. 2016; 7: 206. Ref.: http://bit.ly/2QSHLwv

42. Almeida MI, Reis RM, Calin GA. MicroRNA history: discovery, recent applications, and next frontiers. Mut Res. 2011; 717: 1-8. Ref.: http://bit.ly/2HWDhC9

43. Verma P, Pandey RK, Prajapati P, Prajapati VK. Circulating microRNAs: potential and emerging biomarkers for diagnosis of human infectious diseases. Front Microbiol. 2016; 7: 01274: 1-7. Ref.: http://bit.ly/2Z70IE0

44. Ojha R, Nandani R, Pandey RK, Mishra A, Prajapati VK. Emerging role of circulating microRNA in the diagnosis of human infectious diseases. J Cell Physiol. 2019; 234: 1030-1043. Ref.: http://bit. ly/2wKkVOd

45. Eck M, Schmausser B, Scheller K, Toksoy A, Kraus M, et al. CXC chemokines Gro(alpha)/IL-8 and IP-10/MIG in Helicobacter pylori gastritis. Clin Exp Immunol. 2000; 122: 192-199. Ref.: http://bit. ly/2JYto9j

46. Salvatore CM, Techasaensiri C, Tagliabue C, Katz K, Leos N, et al. Tigecycline therapy significantly reduces the concentrations of inflammatory pulmonary cytokines and chemokines in a murine model of Mycoplasma pneumoniae pneumonia. Antimicrob Agents Chemother. 2009; 53: 15461551. Ref.: http://bit.ly/2QML6gH

47. de Fost M, Chierakul W, Pimda K, Dondorp AM, White NJ, et al. Activation of cytotoxic lymphocytes in patients with scrub typhus. Am J Trop Med Hyg. 2005; 72: 465-467. Ref.: http://bit.ly/2ZcY2z9

48. Lettinga KD, Weijer S, Speelman $P$, Prins JM, Van Der Poll $T$, et al. Reduced interferon-gamma release in patients recovered from Legionnaires' disease. Thorax. 2003; 58: 63-67. Ref.: http://bit.ly/2Z4XueE

49. Shiraki Y, Ishibashi Y, Hiruma M, Nishikawa A, Ikeda S. Candida albicans abrogates the expression of interferon-gamma-inducible protein-10 in human keratinocytes. FEMS Immunol Med Microbiol. 2008; 54: 122-128. Ref.: http://bit.ly/2EThIR6

50. Liu M, Guo S, Hibbert JM, Jain V, Singh N, et al. CXCL10/IP-10 in infectious diseases pathogenesis and potential therapeutic implications. Cytokine Growth Factor Rev. 2011; 22: 121-130. Ref.: http://bit.ly/2HWN5Mo 